\title{
Seroprevalence of Hepatitis B Surface Antigen (HBsAg) among Patients Attending a Tertiary Care Hospital
}

\author{
Prity P. Narwade, Sanjaykumar R. More ", Suresh K. Kandle, \\ Vimal S. Rathod and Supriya M. Emekar
}
Department of Microbiology, Dr. Shankarrao Chavan Government Medical College, Vishnupuri, Nanded-431606, Maharashtra, India

*Corresponding author

\section{Keywords \\ Hepatitis B surface antigen, Immuno Chromatographic assay test, Seroprevalence \\ Article Info \\ Accepted: \\ 10 January 2019 \\ Available Online: \\ 10 February 2019}

\section{A B S T R A C T}

Hepatitis B virus (HBV) infection continues to be a serious public health problem globally. The seroprevalence of Hepatitis B surface antigen among patients attending a tertiary care hospital is useful in assessing true nature of problem, which can help to estimate the magnitude of HBV infection and aid in devising preventive measures. The present study was done to evaluate the seroprevalence of hepatitis B surface antigen among patients attending a tertiary care hospital. The present study was carried out in Department of Microbiology, at a tertiary care hospital, from Jan 2013 to Dec 2018. A total of 57256 patients were included in the study whose venous blood samples were collected, and serum was tested for the presence of $\mathrm{HBsAg}$ using a rapid one step chromatographic immunoassay test kit (OSCAR Laboratories Pvt. Ltd. Delhi). Out of 57256 patients whose blood samples were tested, 1089 were found to be positive for HBsAg giving the prevalence rate as $1.90 \%$, with $602(2.86 \%)$ males and $487(1.34 \%)$ females. The majority of the positive patients belonged to age group 21-40 years $(2.11 \%)$. The present study shows seroprevalence rate of $\mathrm{HBsAg}$ is $1.90 \%$ in economically productive groups. This type of study can be an alternative option for community based studies to formulate strategies for its control and prevention.

\section{Introduction}

Hepatitis B virus (HBV) infection is a global public health problem and causes a spectrum of diseases ranging from self-limiting hepatitis to acute fulminant and chronic hepatitis leading to complications like liver cirrhosis and hepatocellular carcinoma (Quadri et al., 2013; Sood et al., 2013).
HBV infection is the $10^{\text {th }}$ leading cause of death and HBV related hepatocellular carcinoma (HCC) is the $5^{\text {th }}$ most frequent cancer worldwide (Quadri et al., 2013). About more than 2 billion of the world population has serological evidence of past or recent HBV infection and there are more than 350 million chronic carriers of this infection. Approximately 1 million persons die annually from HBV related chronic liver diseases 
including severe complications such as liver cirrhosis and hepatocellular carcinoma (HCC) (Privisani et al., 2002)

The prevalence of HBV infection varies from country to country depending on host and environmental factors. According to $\mathrm{WHO}$ (World Health Organisation) countries are classified as having high (8\% or more), intermediate $(2-7 \%)$, or low (less than $2 \%$ ). HBV endemicity based on the prevalence of hepatitis B carrier state in the general population. India is at the intermediate endemic level of $\mathrm{HBV}$ with prevalence between $2 \%$ to $7 \%$ among the populations studied (Who's Certified, 2002). The prevalence does not vary significantly by region in the country (Parimal et al., 2016). The primary route of transmission of HBV infection is by parenteral like transfusion of blood and its products, dialysis, pricks by contaminated needles, accidental inoculation of infected blood during surgical and dental procedures, immunization, tattooing, ear/nose pricking etc., perinatal transmission from infected mother to child and sexual transmission (Quadri et al., 2013).

The diagnosis of HBV infection is based on clinical symptoms coupled with laboratory findings of serological markers. HBsAg acts as a hallmark of HBV infection as it is the first serological marker to appear in acute $\mathrm{HBV}$ infection and its persistence for more than 6 months suggest chronic HBV infection or development of a carrier state (Khatoon et al., 2016).

Detection of HBsAg is the most commonly used test for diagnosing acute HBV infections as well as for detecting carriers (Naqshbandi et al., 2016). Immunochromatography assays (ICA) are economical and do not require special instrumentation for analysis and have been recommended for routine use in clinical microbiology laboratories for detection of
HBsAg (Sato et al., 1996). The speed, sensitivity and simplicity of the immunochromatography assay (ICA) method makes it more attractive, particularly for large scale surveillance studies (Torlesse et al., 1997; Kaur et al., 2000). With this background, the present study was undertaken to evaluate seroprevalence of $\mathrm{HBsAg}$ among patients.

\section{Materials and Methods}

The present study was carried out in Department of Microbiology, at a tertiary care hospital from Jan 2013 to Dec 2018.Under aseptic precautions from each patient $3 \mathrm{ml}$ of venous blood was withdrawn in a labelled plain vacutainer tube. The blood was allowed to clot followed by centrifugation of the tube at $3000 \mathrm{rpm}$ for 15 minutes to separate serum (Colle et al., 1999). Then, according to manufacturers instruction two drops of serum was tested for the presence of HBsAg using a rapid one-step immune chromatography assay test kit (OSCAR) based on antigen capture or sandwich principle and results were interpreted at 20 minutes. The appearance of red coloured line, one each in the test $\mathrm{T}$ region and control $\mathrm{C}$ region interpreted that the sample was positive for presence of HBsAg, whereas, appearance of red coloured line only in control $\mathrm{C}$ region interpreted that sample was negative for HBsAg.

\section{Results and Discussion}

The study was conducted from Jan 2013 to Dec 2018. A total of 57256 patients were screened for HbsAg of that 1089(1.90\%) were positive for $\mathrm{HbsAg}$.

Among the positive cases the seroprevalence of $\mathrm{HbsAg}$ was found to be high amongst males i.e. 602(2.86\%) than females i.e. $487(1.34 \%)$. Genderwise prevalence of HbsAg is shown in Table 1. 
In this hospital based study prevalence of HbsAg was high in the age group of 21-40 years $(2.11 \%)$ followed by $41-60$ years
(2.03\%) and lowest in 0-20 years (0.71\%). Age wise and year wise prevalence of HbsAg shown in Table 2.

Table.1 Gender wise Prevalence of HbsAg

\begin{tabular}{|c|c|c|c|c|c|c|}
\hline $\begin{array}{c}\text { Yea } \\
\mathbf{r}\end{array}$ & $\begin{array}{c}\text { Male } \\
\text { tested }\end{array}$ & $\begin{array}{c}\text { Male } \\
\text { positive }\end{array}$ & Female tested & Female positive & Total tested & $\begin{array}{c}\text { Total } \\
\text { positive }\end{array}$ \\
\hline $\begin{array}{c}\mathbf{2 0 1} \\
\mathbf{3}\end{array}$ & 3012 & $95(3.1 \%)$ & 5879 & $78(1.32 \%)$ & 8891 & $173(1.94 \%)$ \\
\hline $\begin{array}{c}\mathbf{2 0 1} \\
\mathbf{4}\end{array}$ & 3157 & $113(3.5 \%)$ & 9097 & $105(1.15 \%)$ & 12254 & $218(1.77 \%)$ \\
\hline $\begin{array}{c}\mathbf{2 0 1} \\
\mathbf{5}\end{array}$ & 2735 & $101(3.6 \%)$ & 6653 & $81(1.21 \%)$ & 9388 & $182(1.93 \%)$ \\
\hline $\begin{array}{c}\mathbf{2 0 1} \\
\mathbf{6}\end{array}$ & 3312 & $89(2.6 \%)$ & 4580 & $67(1.46 \%)$ & 7892 & $156(1.97 \%)$ \\
\hline $\begin{array}{c}\mathbf{2 0 1} \\
\mathbf{7}\end{array}$ & 3810 & $91(2.38 \%)$ & 4694 & $72(1.53 \%)$ & 8504 & $163(1.91 \%)$ \\
\hline $\begin{array}{c}\mathbf{2 0 1} \\
\mathbf{8}\end{array}$ & 5031 & $113(2.2 \%)$ & 5296 & $84(1.58 \%)$ & 10327 & $197(1.90 \%)$ \\
\hline $\begin{array}{c}\text { Tot } \\
\mathbf{a l}\end{array}$ & $\mathbf{2 1 0 5 7}$ & $\mathbf{6 0 2}(\mathbf{2 . 8 6 \%})$ & $\mathbf{3 6 1 9 9}$ & $\mathbf{4 8 7})$ & & \\
\hline
\end{tabular}

Table.2 Year wise and age wise prevalence of $\mathrm{HbsAg}$

\begin{tabular}{|l|c|c|c|c|c|c|c|c|c|c|}
\hline Year & \multicolumn{2}{|c|}{$\mathbf{0 - 2 0}$ yrs } & \multicolumn{2}{c|}{$\mathbf{2 1 - 4 0}$ yrs } & \multicolumn{2}{c|}{$\mathbf{4 1 - 6 0}$ yrs } & \multicolumn{2}{|c|}{$>\mathbf{6 0}$ yrs } & \multicolumn{2}{c|}{ Total } \\
\hline & Tested & $\begin{array}{c}\text { Positiv } \\
\text { e }\end{array}$ & Tested & Positive & Tested & $\begin{array}{c}\text { Positiv } \\
\text { e }\end{array}$ & Tested & $\begin{array}{c}\text { Positiv } \\
\text { e }\end{array}$ & Tested & Positive \\
\hline $\mathbf{2 0 1 3}$ & 900 & 6 & 3675 & 76 & 2701 & 59 & 1615 & 32 & 8891 & $173(1.94 \%)$ \\
\hline $\mathbf{2 0 1 4}$ & 682 & 4 & 5127 & 96 & 3881 & 71 & 2564 & 47 & 12254 & $218(1.77 \%)$ \\
\hline $\mathbf{2 0 1 5}$ & 648 & 3 & 3629 & 85 & 3006 & 64 & 2105 & 30 & 9388 & $182(1.93 \%)$ \\
\hline $\mathbf{2 0 1 6}$ & 767 & 6 & 2930 & 66 & 2486 & 48 & 1709 & 36 & 7892 & $156(1.97 \%)$ \\
\hline $\mathbf{2 0 1 7}$ & 638 & 8 & 3234 & 69 & 2952 & 57 & 1680 & 29 & 8504 & $163(1.91 \%)$ \\
\hline $\mathbf{2 0 1 8}$ & 721 & 4 & 3742 & 81 & 3220 & 73 & 2644 & 39 & 10327 & $197(1.90 \%)$ \\
\hline Total & 4356 & 31 & 22337 & 473 & 18246 & 372 & 12317 & 213 & $\mathbf{5 7 2 5 6}$ & $\mathbf{1 0 8 9}$ \\
& & $(0.71 \%)$ & & $(2.11 \%)$ & & $(2.03 \%)$ & & $(1.72 \%)$ & & $(\mathbf{1 . 9 0 \% )})$ \\
\hline
\end{tabular}

In the present study, the seroprevalence was found to be $1.90 \%$, which comes under low endemicity. In accordance with our study, Bulle et al., (2016) and Naqshbandi et al., (2016), also reported seroprevalence of HBsAg of $1.57 \%$ and $1.2 \%$ respectively. Another study conducted by Tripathi et al., (2015), showed seroprevalence of HBsAg at tertiary care centre in Telangana was $1.69 \%$. A review of hepatitis B prevalence in India by
Lodha et al., (2001) has conducted that it is in between 1-2\%. A hospital based study conducted by Patil et al., (2016), found $2.99 \%$ seropositivity in Karad district while Trupti et al., (2018), found $0.56 \%$ seroprevalence in Karnataka. Chowdhary (2004), reported that $3-4 \%$ of the Indian population are HBV infected with the highest prevalence among the aborigines of Andaman as well as from Arunachal Pradesh. 
There is a wide variation in $\mathrm{HBsAg}$ prevalence in different geographical regions in India. The difference may be because of the type of population studied, genetic factors, health factors and socioeconomic status. In general, it is lowest in countries or areas with high standard of living like effective vaccination, improved sanitation and safe transfusion measures (e.g. Austrelia, North America, North Europe) and highest in countries or areas with low socioeconomic levels (e.g. China, South East Asia, South America) (Vazhavandal et al., 2014).

In our study, there was an increase in the seroprevalence rate among the male population $(2.86 \%)$ as compared to that in female $(1.34 \%)$, as shown in Table 1. In accordance with our study, many studies shows male preponderance compared to females. Tripti et al., (2018), reported HbsAg prevalence in males $0.98 \%$ and $0.36 \%$ in females. Gokhale et al., (2017), reported seroprevalence in males $72 \%$ and $28 \%$ in females. Bulle et al., (2016), also showed male preponderance $(2.2 \%)$ than females $(1.33 \%) . H i g h e r$ infection rate in men could be due to their frequent exposure to risk factors such as injecting drug abuse, having multiple sexual partners or other risk behaviours. It is also hypothesized that females clear HBV more efficiently compared to male.

The seropositivity was highest $(2.11 \%)$ among $21-40$ years followed by $41-60$ years $(2.03 \%)$ and lowest $(0.71 \%)$ among 0-20 years, as shown in Table 2. Like our study, most of the studies (Gokale et al.,2017; Bulle et al., 2016) observed seropositivity maximum in second to fourth decade of life. While study of Tripathi et al., (2015), showed highest prevalence in 31-40 years followed by 21-30 years, so it can be concluded that highest prevalence in 21-40 years. The higher prevalence among 21-40 years age group could be due to higher exposure to occupational risk factors as well as high risky behaviour. Further, lowest rate of seropositivity in younger age groups could be due to prevention of perinatal transmission of $\mathrm{HBV}$ by immunization in this locality.
In conclusion, the seroprevalence of $\mathrm{HbsAg}$ is low in our area, although India lies in intermediate to high endemic category. This might be due to effective immunization programme which reduces the burden of infection in our area. The present study also highlights seroprevalence rate of HbsAg higher in economically productive age groups thereby providing reference for future community based studies on epidemiology of HBV infection and also to formulate strategies to further reduce the seroprevalence rate of $\mathrm{HbsAg}$.

\section{References}

Bulle PA, Tekam S, Gedam DS, Gujar V, Deshmukh D. 2016. Prevalence of Hepatitis B surface antigen (HBsAg) positivity among general population in Yavatmal (Maharashtra), India. Int.J.Curr.Microbiol.App.Sci. 5(7): 513517.

Chaudhary A. 2004. Epidemiology of hepatitis B virus in India. Hep B Annual. 1:17-24.

Colle JG, Fraser AG, Marmion BP,Simmons A. Laboratory diagnosis of virus infections. In: Colle JG,Fraser AG, Marmion BP,Simmons A, eds. Mackie and McCartney practical Medical Microbiology. $14^{\text {th }}$ ed. New York: Churchill-Livingstone: 1999.

Gokale SK, Sonth SB, Solabannavar SS. 2017. Seroprevalence of Hepatitis B virus among patients at a tertiary care centre in North Karnataka, India. Int.J.Curr.Microbiol.App. Sci. 6(9):755757.

Kaur H, Dhanao J, Oberoi A. 2000. Evaluation of rapid kits for detection of HIV, HBSAG and HCV infections. Indian $\mathrm{J}$ Med Sci. 54:432-4.

Khatoon R, Jahan N. 2016. Evaluation of seroprevalence of Hepatitis $\mathrm{B}$ virus infection among patients attending a hospital of semiurban North India using rapid immunoassay test. Niger Postgrad Med J. 23:209-214.

Lodha R, Jain Y, Anand K, Kabra SK, Pandava CS.2001. Hepatitis B in India: A review 
of disease epidemiology. Indian Pediatr. 38: 1318-22.

Naqshbandi I, Qadri SYA, Yasmeen N, Bashir N. 2016. Seroprevalence and risk factors of Hepatitis B virus infection among general population of Srinagar Kashmir. International Journal of Contemporary Medical Research. 3(4):1050-1054.

Parimal H. Patel, Alka B. Nerurkar, Mehul R. Patel.2016. Seroprevalence of Hepatitis B Surface Antigen in patients attending a tertiary care hospital Valsad, South Gujarat, India. International Journal of Medical Microbiology and Tropical Diseases, July-September, 2016;2 (3): 103-106.

Patil SR, Ghorpade MV, Patil SS, Pawar SK, Mohite ST. 2016. Seroprevalence of Hepatitis-B surface antigen among the patients reporting at tertiary care Hospital from India. Bangladesh Journal of Medical Science. 15(3): 455-459.

Privisani N, Lavanchy D. World Health Organization. Hepatitis B(WHO/CDS/ CSR/LYO/2002.2)2002

Purti Chandrashekher Tripathi, Trinain Kumar Chakraverti, Nileshkumar Ramniklal Khant. Seroprevalence of hepatitis B surface antigen and antibody to hepatitis $\mathrm{C}$ virus at a tertiary care centre in Telangana. Int J Res Med Sci. 2015; 3(1): 297-300.

Quadri SA, Dadapeer HJ, Arifulla M, Khan N. 2013. Prevalence of Hepatitis B surface antigen in hospital based population in
Bijapur, Karnataka. Al Ameen J Med Sci. 6(2):180-182.

Sato K, Ichiyama S, Iinuma Y, Nada T, Shimokata K, Nakashima NJ. 1996. Evaluation of immune chromatographic assay systems for rapid detection of hepatitis B surface antigen and antibody, Dainascreen HBsAg and Dainascreen Ausab. Clin Microbiol. 34(6): 1420-2.

Sood S. 2013. Serological evaluation of hepatitis B virus in outpatient department patients of a private hospital in Northwest India. National J. Community Medicine. 4; 485-488.

Torlesse H, Wurie IM, Hodges M. 1997. The use of immunochromatography test cards in the diagnosis of hepatitis B surface antigen among pregnant women in West Africa. Br J Biomed Sci. 54(4): 256-9.

Trupti B. Naik, J.V. Sathish and Mita D. Wadekar, Seroprevalence of Hepatitis B Surface Antigen (HBsAg) among Patients Attending a Tertiary Care Hospital at Chamarajanagar, Karnataka, India, Int.J.Curr.Microbiol.App.Sci (2018) 7(1): 1279-1284.

Vazhavandal G, Bharadwaj VGB, Uma A, Rajalakshmi CP. 2014. Seroprevalence of hepatitis B virus among patients at a rural tertiary health care centre in South India: a four year study. Int J Res Med Sci. 2(1): 310-313.

WHO certified (Internet). Prevention of Hepatitis B in India, An overview. World Health Organization, New Delhi. 2002.

\section{How to cite this article:}

Prity P. Narwade, Sanjaykumar R. More, Suresh K.Kandle, Vimal S. Rathod and Supriya M. Emekar. 2019. Seroprevalence of Hepatitis B Surface Antigen (HBsAg) among Patients Attending a Tertiary Care Hospital. Int.J.Curr.Microbiol.App.Sci. 8(03): 1014-1018.

doi: https://doi.org/10.20546/ijcmas.2019.803.123 